\title{
Aplikasi ‘MICE Indonesia’ Pada Smartphone Sebagai Alat Promosi MICE Indonesia Kepada Dunia
}

\author{
Nur Fitri Azizah dan Diana DC Hutagalung \\ Jurusan Administrasi Niaga Politeknik Negeri Jakarta \\ Email : fitriazizahnur@gmail.com hutagalungdiana@yahoo.com
}

\begin{abstract}
Indonesia is currently focus in increasing the number of foreign tourists visiting the destination with leisure and business (MICE) purpose. Various ways have been done by Ministry of Tourism, one of them is made applications for mobile users. Applications that have been launched by Ministry of Tourism are 'Pesona Indonesia eBrochure', 'Wonderful Indonesia', and '100 You Must See in Indonesia' which all of that promote Indonesia's famous destination. The applications are quite effective in describing the wonderful things of Indonesian destinations, but has not been able to provide information related to the MICE industry. In this journal will be discussed about the important role of applications on the smartphone as a promotional tool, comparing the three types of applications that have been launched by the Ministry of Tourism of Indonesia, feature plan in 'MICE Indonesia' applications as a result of the development of the previous three applications. The aims of this journal are to describe the important role of mobile application as a promotional tool in the digital era, knowing the advantages and disadvantages of features in the application launched by the Ministry of Tourism, and to make feature design on 'MICE Indonesia' application as MICE promotion tool to the world. This research method is use case study by making comparison with previous product (applications). The results of this study is 'MICE Indonesia' application is an effective tool in presenting information related to MICE and able to encourage business actors to conduct their MICE activities in Indonesia.
\end{abstract}

Keyword: application, MICE, promotion, smartphone, kontribusi dan peran penting

\begin{abstract}
Abstrak
Indonesia saat ini sedang berkonsentrasi penuh dalam meningkatkan angka kunjungan wisatawan mancanegara dengan tujuan leisure maupun bisnis (MICE). Berbagai cara dilakukan Kementerian Pariwisata salah satunya melakukan promosi destinasi melalui aplikasi di smartphone. Aplikasi yang telah diluncurkan Kementerian Pariwisata adalah 'Pesona Indonesia eBrochure', 'Wonderful Indonesia', dan '100 You Must See in Indonesia' yang ketiganya mempromosikan destinasi andalan Indonesia. Aplikasi tersebut dinilai cukup efektif dalam mendeskripsikan pesona destinasi Indonesia, namun belum mampu memberikan informasi yang bersangkutan dengan bidang MICE. Pada jurnal ini akan dibahas mengenai peran penting aplikasi pada smartphone sebagai alat promosi, membandingkan ketiga jenis aplikasi yang telah diluncurkan oleh Kementerian Pariwisata Indonesia, serta membuat rancangan aplikasi 'MICE Indonesia' sebagai hasil pengembangan ketiga aplikasi sebelumnya. Tujuan yang akan dicapai adalah mengetahui peran penting penggunaan aplikasi pada smartphone sebagai alat promosi di era digital saat ini, mengetahui kekurangan serta kelebihan fitur-fitur dalam aplikasi yang diluncurkan Kementerian Pariwisata, dan membuat rancangan fitur pada aplikasi 'MICE Indonesia' sebagai alat promosi MICE kepada dunia. Metode penelitian ini adalah studi kasus yaitu dengan membuat perbandingan dengan produk sebelumnya. Adapun hasil penelitian ini adalah aplikasi 'MICE Indonesia' merupakan alat yang efektif dalam menyajikan informasi terkait MICE dan mampu mendorong pelaku bisnis dunia untuk melakukan kegiatan MICE nya di Indonesia.
\end{abstract}

Kata Kunci: aplikasi, MICE, promosi, smartphone., contribution and important role 


\section{PENDAHULUAN}

Indonesia melalui Kementerian Pariwisata saat ini sedang fokus terhadap program peningkatan angka kunjungan wisman (wisatawan mancanegrara) dengan target hingga akhir 2017 sejumlah 15 juta pengunjung. Angka kunjungan hingga akhir September 2017, tercatat sudah mencapai 10,46 juta naik 25.05\% dari tahun sebelumnya (Kompas, 2017).

Dalam mempromosikan MICE Indonesia, pemerintah melakukannya dengan berbagai cara, diantaranya: menjadi peserta event pameran B2B diberbagai negara, membuat event menarik dengan tujuan memperluas relasi dengan komunitas para pelaku MICE di dunia, melakukan promosi cetak dibeberapa negara, dan melibatkan media digital seperti web, media sosial, dan aplikasi pada smartphone (Android dan IOS).

Pemerintah nampaknya sudah mulai menyadari bahwa saat ini telah terjadi revolusi era menjadi era digital. Era salah satunya telepon seluler (smartphone). Menurut eMarketer (2017), 4 dari 5 pengguna internet diseluruh dunia menggunakan smartphone untuk menemukan informasi, mencari pencerdasan, menyelesaikan permasalahan, bersosialisasi, berkomunikasi, berbagi file menggunakan cloud storage, menggunakan aplikasi, menonton film, mendengarkan musik, bermain game, menjual dan membeli barang, memasarkan produk, dan menemukan pelanggan.

Pengguna internet memilih smartphone sebagai perangkat untuk memenuhi kebutuhan mereka karena smartphone dinilai praktis penggunaannya, dapat diakses kapan saja dan di mana saja karena mudah dibawa kemana-mana.

Para pelaku bisnis cepat tanggap dalam melihat fenomena ini. Mereka berpikir bagaimana strategi pemasaran yang tepat melalui media digital pada smartphone yang digemari masyarakat dunia. digital didominasi oleh para generasi Millennial dengan cakupan usia 17-37 tahun dan para generasi Z (di bawah 17 tahun). Kedua generasi ini didefinisikan sebagai kelompok sosial yang sudah 'melek' terhadap teknologi sehingga mereka banyak melakukan aktivitasnya di internet.

Angka pengguna internet di Indonesia ternyata menduduki peringkat lima tertinggi dari seluruh dunia yaitu sebanyak 132.700 .000 pengguna. Peringkat pertama diduduki oleh China dengan 738.539.792 pengguna, lalu diikuti oleh India dengan 462.124.989 pengguna, United State dengan 286.942.362 pengguna, dan Brazil dengan 139.111.185 pengguna. Adapun total pengguna internet diseluruh dunia mencapai 3.885.567.619 pengguna (Internet World Stats, 2017).

Dari data tersebut dapat disimpulkan sekitar $47 \%$ dari seluruh populasi di dunia sudah menjadi pengguna internet. Internet dapat diakses melalui berbagai macam perangkat

Beberapa dari mereka akhirnya mendirikan web perusahaan. Namun, web perusahaan tidak mudah menyesuaikan diri apabila dibuka melalui perangkat smartphone sehingga dibutuhkan suatu sistem mobile user friendly. Sistem tersebut adalah aplikasi dalam PlayStore (Android) dan AppStore (iOS).

Kementerian Pariwisata Indonesia sejak tahun 2015 meluncurkan tiga aplikasi yang berjudul 'Pesona Indonesia eBrochure', 'Wonderful Indonesia', dan '100 You Must See in Indonesia'. Ketiga aplikasi tersebut berisi fitur-fitur online yang menampilkan pesona destinasi Indonesia. Ketiga aplikasi tersebut sudah di download oleh 5.000-10.000 pengguna internet. Minimnya angka downloaders aplikasi tersebut disebabkan oleh jarang diperbaharuinya informasi dalam aplikasi tersebut dan tidak ada pengembangan yang konstan dalam perbaikan sistem.

Fitur yang terdapat dalam aplikasi secara keseluruhan mencakup informasi 
destinasi, peta petunjuk, informasi kuliner, jadwal event, dan atraksi wisata. Fitur tersebut sudah dapat dikatakan bertujuan mempromosikan destinasi Indonesia namun tidak untuk promosi MICE Indonesia.

Oleh sebab itu, saya tertarik untuk membuat gagasan sebuah aplikasi pada smartphone yang memiliki tujuan fokus kepada promosi MICE Indonesia, yang akan dijelaskan pada jurnal dengan judul “Aplikasi 'MICE Indonesia' Pada Smartphone Sebagai Alat Promosi MICE Indonesia Kepada Dunia”.

\section{METODE PENELITIAN}

Penelitian ini menggunakan metode studi kasus dimana Penulis akan menganalisis tiga aplikasi yang diluncurkan Kementerian Pariwisata, sebagai bahan evaluasi untuk desain pengembangan aplikasi yang akan digarap.

Dalam mencari dasar ilmunya, Penulis melakukannya dengan mempelajari dan melibatkan hasil penelitian dari peneliti sebelumnya, hasil riset lembaga atau asosiasi, dan melakukan browsing di halaman-halaman situs web terpercaya.

Penelitian dilakukan terhitung sejak tanggal 21-22 Desember 2017. Alat yang digunakan adalah aplikasi PlayStore pada Andorid dan aplikasi AppStore pada iOS. Adapun hasil penelitian ini berupa data kualitatif.

\section{HASIL DAN PEMBAHASAN Temuan}

Dari tujuan penulisan yang telah dijelaskan di atas, maka temuan yang didapat Penulis sebagai berikut:

a. Peran Penting Aplikasi Smartphone Sebagai Alat Promosi Menurut Melanie Haselmayr (2016):

(1) Diakses Pelanggan Setiap Waktu Penelitian menyatakan bahwa rata-rata pengguna Internet di Amerika menghabiskan waktu dua jam dalam satu hari dalam mengakses internet melalui smartphone. Dalam waktu dua jamnya tersebut pasti ada aplikasi yang digunakannya, karena otak dapat menaruh memori berupa simbol dan warna (dalam konteks logo aplikasi) dengan baik. Sehingga secara terencana atau tidak, pelanggan pasti akan membuka aplikasi dalam setiap menggunakan internet.

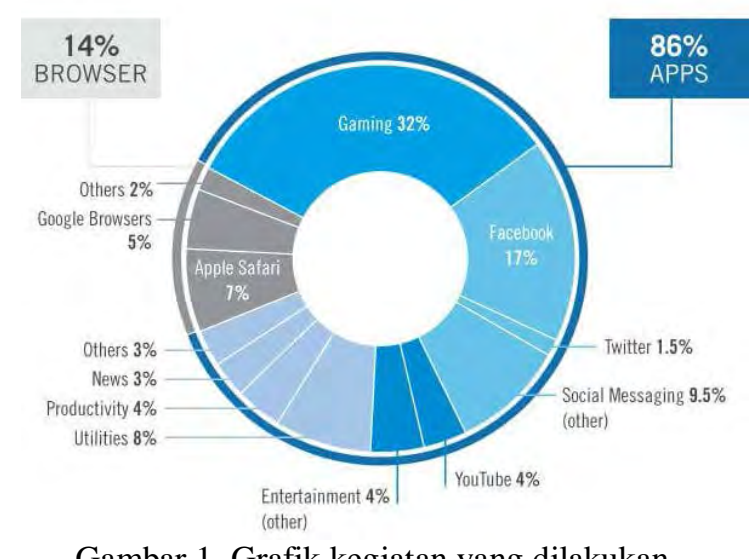

Gambar 1. Grafik kegiatan yang dilakukan pengguna internet pada perangkat Android dan iOS (Sumber: Flurry Analytics, ComScore, Net Market Share)

(2) Terbentuknya Saluran Pemasaran Langsung

Aplikasi melayani banyak fungsi seperti: memberikan info umum, harga, formulir pemesanan, fitur pencarian, akun pengguna, utusan, umpan berita, dan masih banyak lagi.Salah satu manfaat terbesar memiliki aplikasi seluler adalah semua informasi yang ingin dibagikan perusahaan berikan kepada pelanggan ada di ujung jari mereka. Melalui menu notifikasi, perusahaan semakin dekat melalui interaksi langsung, dan dapat dengan mudah mengingatkan pelanggan tentang produk dan layanan perusahaan kapan pun.

(3) Membangun Brand dan Recognition

Brand: Aplikasi seluler seperti tanda papan reklame kosong. perusahaan bisa melakukan apa yang Anda inginkan dengannya; bisa membuatnya bergaya, hip, fungsional, mengejutkan, atau 
informatif sesuai dengan citra brand yang ingin dibangun.

Recognition. Semakin sering perusahaan bisa membuat pelanggan terlibat dengan aplikasinya, semakin cepat mereka cenderung membeli produk dan / atau layanan perusahaan.

\section{(4) Stand Out Dari Kompetisi}

Aplikasi seluler saat ini di tingkat bisnis kecil masih jarang terjadi, dan ini adalah saat dimana perusahaan bisa melompati pesaing dimasa depan. Menjadi yang pertama diantara pesaing bisnis lainnya untuk menawarkan produk melalui aplikasi seluler.

\section{(5) Berkembangnya Loyalitas} Pelanggan

Terakhir, namun tidak kalah pentingnya, alasan terpenting mengapa harus mempertimbangkan untuk membuat aplikasi seluler sendiri karena loyalitas pelanggan. Dengan semua kejenuhin di luar sana: spanduk pinggir jalan, papan reklame, tanda berkedip, iklan surat kabar, selebaran, kupon, situs web, spanduk situs web, iklan Facebook, dan pemasaran email. Saya tidak mengatakan bahwa aplikasi seluler akan menyelamatkan bisnis Anda, namun ini bisa menjadi cara untuk tetap dekat dengan pelanggan Anda, dan menjadi "ujung jari" setiap saat.

\section{b. Perbandingan Aplikasi Milik}

Kemeterian Pariwisata

(1) Pesona Indonesia eBrochure Aplikasi Pesona Indonesia memiliki 5 fitur utama yaitu: Wisata (menampilkan informasi macammacam wisata alam, budaya, bahari,dan buatan yang ada di Indonesia), Kalender Event (berisi jadwal event besar di Indonesia), Maps (terhubung ke GPS untuk mengetahui atraksi wisata sekitar pengguna aplikasi), Tentang Aplikasi (membahas maksud dan tujuan aplikasi diluncurkan), dan Pengaturan.

Jumlah downloaders: 10.000-50.000. Terakhir diperbaharui: 16 Desember 2016.

Keluhan pengguna: informasi destinasi wisata tidak lengkap, tampilan aplikasi kurang bagus dan kurang lengkap, tidak ada informasi aksesibilitas, hanya menginformasikan destinasi terkenal saja, dan informasi yang disajikan tidak up to date (basi).

(2) Wonderful Indonesia

Aplikasi Wonderful Indonesia memiliki 5 fitur utama yaitu: Destination (menampilkan spot destinasi yang menjadi fokus untuk dipromosikan), Kalender Event (berisi jadwal event dan deskripsinya), Maps (berisi info destinasi terdekat, restoran, akomodasi, dan lainnya), Tentang Kami, dan Pengaturan.

Jumlah downloaders: 5.000-10.000

Terakhir diperbaharui: 20 Oktober 2016

Keluhan pengguna: beberapa menyajikan informasi yang salah dan jadwal event tidak update.

(3) 100 You Must See in Indonesia Aplikasi ini hanya memiliki satu fitur yaitu Filter. Filter berisi pilihan-pilihan untuk menyaring informasi yang dibutuhkan. Pilihan-pilihan tersebut disaring berdasarkan historical, cultural, wildlife, entertainment, shopping, geopark, health \& spa, dive site, beaches, event. Setiap destinasi yang dimunculkan memberikan informasi maps, lokasi, gambaran umum, dan tips.

Jumlah downloaders: $1.000-5.000$

Terakhir diperbaharui: 28 Desember 2015

Keluhan pengguna: (tanpa tanggapan)

c. Menurut Ravi Jada (2017), hasil penelitian yang dilakukan oleh iMOBDEV Technologies menyatakan 
tujuan turis menggunakan travel dan tourism app:

(1) Menggunakan fitur maps - 49.1\%

(2) Mencari restoran - 62.1\%

(3) Menggunakan GPS untuk arah $48.1 \%$

(4) Mencari hotel - 46\%

(5) Mencari atraksi wisata sekitar $33.3 \%$ $\%$

(6) Melakukan check in pesawat - 23.9

(7) Membeli tiket transportasi - 8.1\%

(8) Mencari transportasi umum $12.6 \%$

(9) Mencari tempat belanja - 36.1\%

(10) Memeriksa cuaca - 55.8\%

\section{Pembahasan}

Membuat aplikasi mobile user friendly untuk mendukung pemasaran produk menjadi nilai tambah bagi perusahaan di era digital saat ini. Selain situs web dan media sosial, diperlukan sistem lain untuk menjangkau pasar lebih luas dan untuk memudahkan pelanggan dalam menerima informasi yang ingin disampaikan perusahaan.

Kementerian Pariwisata Indonesia memiliki produk yang perlu dipasarkan ke dunia internasional dalam bentuk destinasi wisata dan MICE. Langkah konkret yang dilakukan Kementerian Pariwisata melalui media digital salah satunya adalah pembuatan aplikasi pariwisata Indonesia.

Aplikasi yang telah diluncurkan nampaknya belum digarap secara matang dari segi kesiapan informasi yang ada di dalamnya. Informasi yang disajikan dalam aplikasi masih sebatas mempromosikan destinasi wisata dan menampilkan akomodasi, restoran, dan atraksi wisata terdekat. Padahal fitur-fitur tersebut sama sekali tidak mewakili kebutuhan infromasi untuk para pelaku MICE yang datang ke Indonesia.

Dari perbandingan ketiga aplikasi Kementerian Pariwisata yang telah dianalisis pada bagian sebelumnya, Penulis terinspirasi untuk membuat gagasan baru berupa aplikasi yang menyajikan fitur-fitur pendukung kebutuhan para pelaku MICE di Indonesia seperti venue, akomodasi, transportasi, aksesibilitas, keamanan, dan atraksi wisata sekitar. Informasi tersebut akan dimasukkan ke dalam fitur-fitur dalam aplikasi 'MICE Indonesia' yang dapat diakses oleh para pengguna smartphone Android maupun iOS. Berikut ini fiturfitur rancangan yang ada dalam aplikasi 'MICE Indonesia':

a. Fitur Destinasi

Fitur ini berisi 16 pilihan destinasi MICE Indonesia yaitu Jakarta, Bali, Bandung, Surabaya, Solo, Yogyakarta, Makasar, Batam, Medan, Manado, Padang, Palembang, Balikpapan, Bintan, Semarang, dan Lombok. Setelah pengguna memilih salah satu destinasi tersebut maka akan muncul fitur-fitur lainnya.

b. Fitur Venue

Fitur venue berisi informasi convention center dan stadion olahraga dari destinasi yang dipilih. Setelah memilih venue yang diminati lalu akan muncul gambaran umum dan informasi venue meliputi kapasitas, luas ruangan, jumlah ruangan, lokasi, dan daftar event yang pernah dilaksanakan di venue tersebut. Fitur ini juga dilengkapi dokumentasi venue agar pengguna aplikasi ini mempunya bayangan terhadap venue yang akan dipilihnya.

c. Fitur Akomodasi

Pada fitur ini, sistem aplikasi akan menanyakan terlebih dahulu venue apa yang akan digunakan untuk kegiatan MICE para pengguna aplikasi. Setelah kolom pertanyaan diisi, sistem akan mencari hotel sekitar venue tersebut. Hotel diurutkan berdasarkan rating dan disetiap informasi hotel terdapat nama hotel, lokasi, jumlah ruangan, tipe kamar, dan kontak hotel agar pengguna aplikasi dapat menghubungi informasi lebih lanjut langsung ke hotel yang bersangkutan. 


\section{d. Fitur Transportasi}

Pada fitur ini, sistem aplikasi akan menanyakan terlebih dahulu dari dan ke mana tujuan pengguna aplikasi. Setelah diisi, sistem akan mencari transportasi apa yang paling mudah digunakan dan bagaimana aksesibilitasnya.

e. Fitur Atraksi Wisata

Fitur ini dapat berkolaborasi dengan aplikasi promosi destinasi yang sudah digarap oleh Kementerian Pariwisata sebelumnya. Sistem akan mencari tahu atraksi wisata terdekat dari venue pengguna aplikasi. Fitur ini nantinya dapat berguna sebagai rekomendasi optional tour setelah pelaksana MICE menyelesaikan bisnisnya.

f. Fitur Perjalananmu

Fitur ini menampilkan rangkuman hasil pilihan yang telah dipilih oleh pengguna aplikasi mulai dari pemilihan venue, akomodasi, transportasi, dan atraksi wisata. Sistem pada aplikasi akan membuat jadwal perjalanan dan denak perjalanan MICE pengguna aplikasi. Perjalanan tersebut nantinya dapat disimpan dalam aplikasi maupun di download agar dapat diakses secara offline.

g. Fitur Berita

Fitur ini berisi berita yang terkait dengan informasi pariwisata dan MICE di Indonesia. Dari fitur ini, pengguna aplikasi dapat mengetahui informasi terkini dan keamanan di Indonesia agar dapat menjalankan perjalanannya dengan tenang.

h. Fitur Jadwal Event

Fitur ini menampilkan informasi event skala nasional dan internasional yang diselenggarakan di Indonesia.

i. Fitur Tentang Kami

Fitur ini berisi informasi tentang Kementerian Pariwisata Republik Indonesia.
Delapan fitur tersebut merupakan rancangan dari Penulis untuk aplikasi 'MICE Indonesia' yang diharapkan mampu membantu dan memfasilitasi para pelaku bisnis yang tertarik untuk menjadikan Indonesia sebagai venue pelaksanaan kegiatan bisnisnya tersebut.

Pada akhirnya tujuan yang ingin dicapai adalah meningkatnya angka pelaku kegiatan MICE di Indonesia dan meningkatkan devisa negara lebih cepat dari wisman dengan tujuan hanya melancong.

\section{KESIMPULAN DAN SARAN Kesimpulan}

Dari penjelasan di atas dapat disimpulkan bahwa Kementerian Pariwisata telah berupaya mempromosikan destinasi dan MICE di Indonesia salah satunya dengan membuat aplikasi mobile user friendly yaitu 'Pesona Indonesia eBrochure', 'Wonderful Indonesia', dan '100 You Must See in Indonesia'

Pada pengaplikasiannya, ketiganya hanya mempromosikan destinasi potensial Indonesia saja dan terdapat banyak kekurangan dalam aksesnya. Sehingga Penulis memiliki gagasan baru untuk mempromosikan MICE Indonesia melalui aplikasi bernama 'MICE Indonesia' sebagai salah satu alat promosi dan juga kemudahan yang diberikan untuk para pelaku bisnis yang ingin mencari informasi mengenai komponen MICE di Indonesia.

\section{Saran}

Penulis menyarankan untuk dilakukannya penelitian lanjutan terkait desain fitur pada aplikasi 'MICE Indonesia' dan peninjuan kembali terkait urgensi dibuatnya aplikasi tersebut.

Penulis juga berharap pengajuan dibuatnya aplikasi 'MICE Indonesia' dapat menjadi pertimbangan bagi Kementerian Pariwisata sebagai salah satu alat promosi yang digarap serius, menimbang saat ini sudah masuk ke era 
digital di mana melibatkan media digiital dalam promosi MICE kepada dunia merupakan suatu prioritas yang harus diutamakan.

\section{DAFTAR PUSTAKA}

Yudhianto. 2017. “132 Juta Pengguna Internet Indonesia, 40\% Penggila Medsos” (https://www.detik.com diakses 21 Desember 2017).

Internet World Stats. 2017. "Top 20 Countries With the Highest Number of Internet Users" (http://www.internetworldstats.com diakses 21 Desember 2017).

E-Marketer. 2017. "eMarketer Updates Worldwide Internet and Mobile User Figures" (https://www.emarketer.com diakses 21 Desember 2017).

Prodjo, Wahyu Adityo. 2017. "Menpar Prediksi Target Kunjungan Wisman Tahun 2017 Tidak Tercapai” (http://www.travel.kompas.com diakses 22 Desember 2017).

Weider, Karen. 2016. "Why do people use the internet?"

(https://www.weiderweb.com diakses 22 Desember 2017).

Jada, Ravi. 2017. "Top 5 Advantages of Mobile Apps for Travel \& Tourism Industry" (https://www.imobdevtech.com diakses 22 Desember 2017) 
